Article

\title{
Prevalence of Fusarium fungi and Deoxynivalenol Levels in Winter Wheat Grain in Different Climatic Regions of Poland
}

\author{
Adam Okorski ${ }^{1, *(\mathbb{D}}$, Alina Milewska ${ }^{1}$, Agnieszka Pszczółkowska ${ }^{1}$, Krzysztof Karpiesiuk $^{2}{ }^{\circledR}$, Wojciech Kozera ${ }^{2}{ }^{\circledR}$, \\ Joanna Agnieszka Dąbrowska ${ }^{1}$ and Justyna Radwińska ${ }^{3}$ (i)
}

1 Department of Entomology, Phytopathology and Molecular Diagnostics, Faculty of Agriculture and Forestry, University of Warmia and Mazury in Olsztyn, Plac Łódzki 5, 10-727 Olsztyn, Poland; alina.charenska2209@gmail.com (A.M.); agnieszka.pszczolkowska@uwm.edu.pl (A.P.); joanna.dabrowska@uwm.edu.pl (J.A.D.)

2 Department of Pig Breeding, Faculty of Animal Bioengineering, University of Warmia and Mazury in Olsztyn, Oczapowskiego 5, 10-719 Olsztyn, Poland; krzysztof.karpiesiuk@uwm.edu.pl (K.K.); wojciech.kozera@uwm.edu.pl (W.K.)

3 Department of Internal Diseases with Clinic, Faculty of Veterinary Medicine, University of Warmia and Mazury in Olsztyn, Oczapowskiego 14, 10-718 Olsztyn, Poland; justyna.radwinska@uwm.edu.pl

* Correspondence: adam.okorski@uwm.edu.pl; Tel.: +44-895232492

Citation: Okorski, A.; Milewska, A. Pszczółkowska, A.; Karpiesiuk, K.; Kozera, W.; Dąbrowska, J.A.; Radwińska, J. Prevalence of Fusarium fungi and Deoxynivalenol Levels in Winter Wheat Grain in Different Climatic Regions of Poland. Toxins 2022, 14, 102. https://doi.org/ $10.3390 /$ toxins 14020102

Received: 3 December 2021

Accepted: 25 January 2022

Published: 28 January 2022

Publisher's Note: MDPI stays neutra with regard to jurisdictional claims in published maps and institutional affiliations.

Copyright: (C) 2022 by the authors. Licensee MDPI, Basel, Switzerland. This article is an open access article distributed under the terms and conditions of the Creative Commons Attribution (CC BY) license (https:// creativecommons.org/licenses/by/ $4.0 /$ )

\begin{abstract}
Fusarium head blight (FHB) caused by fungi of the genus Fusarium is one of the most dangerous crop diseases, which has a wide geographic distribution and causes severe economic losses in the production of major cereal species. The infection leads to the accumulation of mycotoxins in grains, which compromises its suitability for human and animal consumption. The study demonstrated that grain samples from warmer regions of Poland, including Sulejów and Tomaszów Bolesławicki (results differed across years of the study), were colonized mainly by F. graminearum and were most highly contaminated with deoxynivalenol (DON). Samples from Northeastern Poland, i.e., Ruska Wieś, which is located in a cooler region, were characterized by a predominance of Fusarium species typical of the cold climate, i.e., Fusarium poae and Penicillium verrucosum. A Spearman's rank correlation analysis revealed that the severity of grain infection with F. avenaceum/F. tricinctum was affected by the mean daily temperature and high humidity in May, and the corresponding values of the correlation coefficient were determined at $\mathrm{R}=0.54$ and $\mathrm{R}=0.50$. Competitive interactions were observed between the F. avenaceum/F. tricinctum genotype and DON-producing F. culmorum and F. graminearum, because the severity of grain infections caused by these pathogens was bound by a negative correlation.
\end{abstract}

Keywords: deoxynivalenol; F. avenaceum; F. graminearum; qPCR; competition; synergy; climate change

Key Contribution: Identification of naturally occurring Fusarium species and contamination of winter wheat grain with deoxynivalenol in different climatic regions of Poland and Europe.

\section{Introduction}

Cereal crops are exposed to various types of environmental stress associated with the availability of water, light and minerals, as well as bacterial and fungal infections [1]. The rapid increase in area under winter wheat and the high share of cereals in the structure of arable land increase the severity of fungal diseases. Winter wheat is susceptible to many diseases that can decrease yields [2,3]. Cereal diseases caused by fungi of the genus Fusarium include seedling blight that leads to pre- and post-emergence damping off [4], Fusarium foot rot [5] and Fusarium head blight (FHB) [6]. On the global scale, FHB is considered the most dangerous disease of wheat that generates the greatest economic losses. Severe FHB outbreaks have been reported every 4 to 5 years in the USA, China, the European Union (EU), Great Britain, Africa and Brazil [7]. FHB is caused by fungi 
of the genus Fusarium [2], and F. graminearum is the most prevalent pathogen around the world [8,9]. In Poland, the predominant Fusarium pathogens of cereals, including winter wheat, include F. avenaceum, F. crookwellense, F. culmorum, F. equiseti, F. graminearum, F. langsethiae, F. sporotrichioides, F. oxysporum, F. poae and F. tricinctum [10-13].

Saprotrophic mycelia in crop residues, chlamydospores and conidia that are spread by wind, rain and insects in the flowering stage are the main sources of FHB infection in successive years $[6,14]$. Fungal spores germinate on the surface of spikelets, and the mycelium penetrates spikelets passively through the stomata or actively through the cell walls. Fusarium fungi secrete numerous hydrolyzing enzymes that facilitate the penetration of host tissues [15]. Infected kernels are smaller, shriveled and white to light pink in color [6].

Due to rapid industrial growth powered mainly by fossil fuels, carbon dioxide $\left(\mathrm{CO}_{2}\right)$ concentrations in the atmosphere exceeded $409 \mathrm{\mu mol} \mathrm{mol}^{-1}$ in 2019, which could contribute to climate change [16]. Global climate change affects plant growth, photosynthetic parameters, crop yields and seed/grain quality parameters such as the protein content [17]. Increasing atmospheric $\mathrm{CO}_{2}$ levels influence the seed germination capacity; seed vigor; moisture content; health status and physical parameters such as size, shape, weight and color [18].

The territory of Poland covers several climatic regions that differ in temperature [19], ranging from the coldest $5 \mathrm{~B}$ region in the northeast to the mildest $7 \mathrm{~B}$ region in the coastal zone of Northwestern Poland. Climate change increases temperatures and decreases precipitation levels in Central Europe and in other regions of the world [20,21]. According to the latest research on the Polish climate, the coldest $5 \mathrm{~B}$ region has nearly disappeared, whereas the milder 7A and 6B regions have been visibly expanded [22]. The severity of FHB is determined mainly by weather conditions in the flowering stage when wheat stands are most often infected [23]. Precipitation, humidity and temperature significantly influence the severity of the disease symptoms [24]. According to epidemiological studies, the incidence of FHB is determined by the presence of the inoculum during the growing season, sporulation rate, duration of the infectious stage and inoculum potential [25].

Fungi that cause FHB produce toxic metabolites that directly damage kernels and can be accumulated in stored grains [6]. Trichothecenes are an important group of mycotoxins produced by Fusarium fungi [26]. Trichothecenes have been divided into four groups (A, B, C and D) based on structural differences. Type A (T-2, HT-2, neosolaniol and diacetoxyscirpenol) and type $\mathrm{B}$ (deoxynivalenol-DON, DON derivatives, nivalenol and fusarin X) trichothecenes are ubiquitous in the environment [27]. Trichothecenes are the leading group of Fusarium mycotoxins that cause chronic or even lethal toxicoses in both humans and animals. These compounds exert toxic effects by inhibiting ribosomal protein synthesis. Trichothecenes are a large and diverse group of compounds, but T-2 mycotoxin, nivalenol (NIV), DON and diacetoxyscirpenol (DAS) are most frequently identified in cereal grains [28]. Deoxynivalenol is detected mainly in wheat and barley, and it is less frequently noted in oat and rye grains. On average, DON is identified in $57 \%$ of wheat samples worldwide [29]. The discussed compounds exert neurotoxic and teratogenic effects, and they can cause acute and chronic immune disorders in humans and animals [30]. According to the latest literature, new research programs are needed to address the impact of global climate change on the risk of FHB infections in cereals [31].

The present study was undertaken to explore this problem. The aim of this study was to determine the prevalence of DON-producing Fusarium fungi and the concentration of DON in wheat grains grown in different climatic regions of Poland and to describe the interactions between DON-producing fungi and other Fusarium species in the analyzed grains.

\section{Results}

\subsection{Culture-Based Morphological Method for the Identification of Fungi}

A total of 1598 fungal isolates belonging to 21 taxa and selected isolates classified as nonsporulating fungi were obtained from the grains of both wheat varieties during in the study (Table S1). The most prevalent species, A. alternata and E. nigrum, accounted for 
$69.77 \%$ and $17.02 \%$ of all the isolates, respectively. Fusarium fungi accounted for $6.07 \%$ of the examined isolates and were represented by eight taxa (F. avenaceum, F. culmorum, F. equiseti, F. graminearum, F. oxysporum F. poae, F. sporotrichioides and F. tricinctum), as well as individual isolates that were identified to the genus level only. In both years of the study, most Fusarium isolates were isolated from wheat grain in Ruska Wieś (Table S1 and Figure S1).

\subsection{Quantification of F. culmorum and F. graminearum DNA by qPCR and Quantification of DON by HPLC}

A multiple analysis of variance revealed that the level of grain infection by Fusarium fungi measured by the qPCR method was affected by location but not by wheat variety (Table 1).

Table 1. The effects of the main factors (location and winter wheat variety) and their interactions on the quantity of DNA of the selected fungi and DON levels in winter wheat grains determined by two-way ANOVA.

\begin{tabular}{cccc}
\hline Parameter & Location (L) & Variety (V) & L $\times$ V \\
\hline F. avenaceum/F. tricinctum DNA & $* *$ & $\mathrm{~ns}$ & $* *$ \\
F. culmorum DNA & $*$ & $\mathrm{~ns}$ & $*$ \\
F. graminearum DNA & $* *$ & $\mathrm{~ns}$ & $* *$ \\
F. poae DNA & $* * *$ & $*$ & $* *$ \\
P. verrucosum DNA & $* * *$ & $\mathrm{~ns}$ & $* *$ \\
DON $(\mu \mathrm{g} / \mathrm{kg})$ & $* *$ & $\mathrm{~ns}$ & $*$ \\
\hline
\end{tabular}

* Significant at $p \leq 0.05,{ }^{* *}$ significant at $p \leq 0.01,{ }^{* * *}$ significant at $p \leq 0.001$ and ns-not significant.

Multiple analyses of variance showed that the level of grain infection by Fusarium fungi measured by the qPCR method depends on the location but not the variety of wheat.

The qPCR analysis revealed that the quantity of F. culmorum DNA varied across the years of the study (Figure 1A,B). In the first year, the highest amount of F. culmorum DNA was found in Pawłowice and Kościelna Wieś, and its amount was significantly lower in the remaining locations. Significant differences were found between locations in region $6 \mathrm{~B}$ (Figure 1A,C and Table S2). In the second year, no differences in the quantity of F. culmorum DNA were noted between locations or climate regions (Figure 1B). The statistical analysis demonstrated that, during the study, the average quantity of F. culmorum DNA ranged from 0.99 pg in Ruska Wieś to 4.89 pg in Kościelna Wieś and 5.08 pg in Pawłowice (Figure 1C). The average quantity of F. culmorum DNA was the highest (4.01 pg) in winter wheat grains grown in climatic region $6 \mathrm{~B}$ and lowest $(0.9 \mathrm{pg})$ in region $5 \mathrm{~B}$ (Figure $1 \mathrm{C})$.

Fusarium graminearum, another DON-producing species of the genus Fusarium, was more prevalent in winter wheat grains other than F. culmorum (Figure 1A-C and Table S2). The amount of F. graminearum DNA in the wheat grains was higher in the first year of the study than in the second year (Figure 2A,B). In 2015, the quantity of F. graminearum DNA was the highest (224.74 pg) in winter wheat grown in Sulejów and the lowest in winter wheat cultivated in Tomaszów Bolesławicki $(8.40 \mathrm{pg})$ (Figure $2 \mathrm{~A})$. In the second year of the study, the results of the qPCR analysis were different. The quantity of F. graminearum DNA was the highest in Tomaszów Bolesławicki (334.06 pg) and lowest in Ruska Wieś, Kościelna Wieś and Białogard at $8.14 \mathrm{pg}, 6.75 \mathrm{pg}$ and $7.26 \mathrm{pg}$, respectively (Figure 2B). The qPCR identification of F. graminearum revealed differences in the quantity of F. graminearum DNA within climate regions 6A (first year of study) and 7A (second year of study) (Figure 2A,B). The average quantity of F. graminearum DNA was the highest (299.68 pg) in winter wheat grown in Sulejów and the lowest in winter wheat cultivated in Białogard (63.45 pg), Kościelna Wieś (47.80 pg) and Ruska Wieś (17.80 pg) (Figure 2C). The average quantity of F. graminearum DNA was the lowest in the grains of winter wheat grown in region $5 \mathrm{~B}(17.81 \mathrm{pg})$. 
A

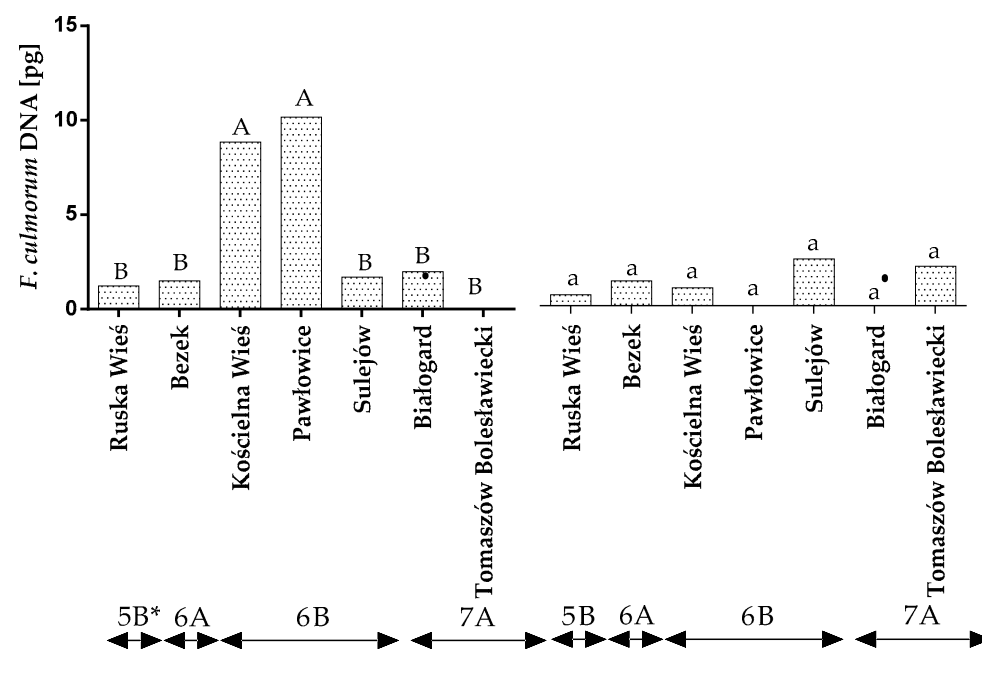

C

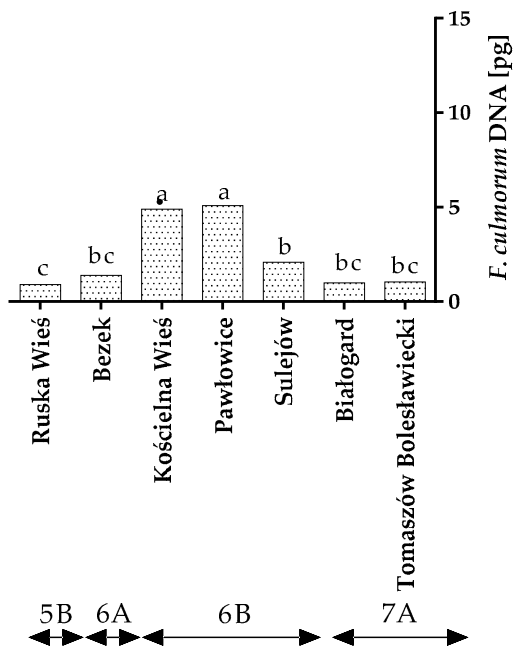

Figure 1. Quantity of F. culmorum DNA (pg) in winter wheat grains grown in different locations in Poland (* climatic regions) (A) during 2015, (B) during 2016 and (C) the average over the years of the study. $\mathrm{a}, \mathrm{b}$ and $\mathrm{c}$ - significant at $p \leq 0.05 ; \mathrm{A}, \mathrm{B}$ and $\mathrm{C}$ - significant at $p \leq 0.01$.

A

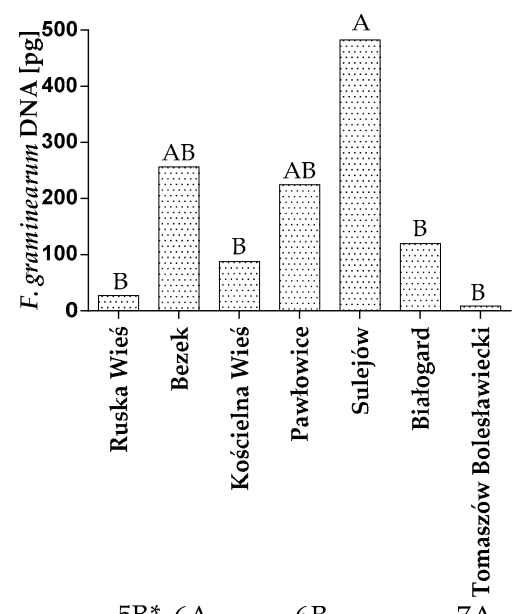

B

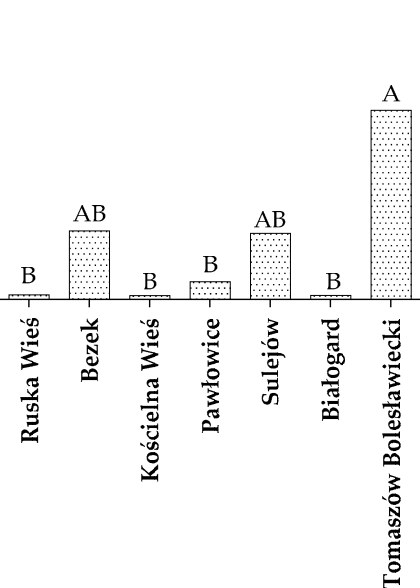

C

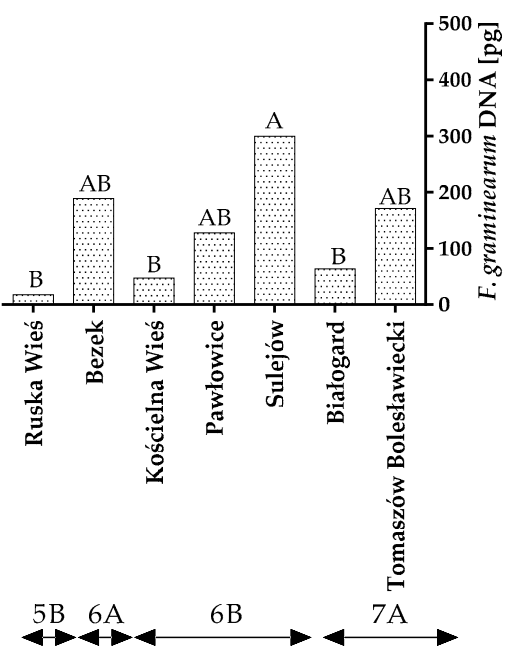

Figure 2. Quantity of F. graminearum DNA (pg) in winter wheat grains grown in different locations in Poland (* climatic regions) (A) during 2015, (B) during 2016 and (C) the average over the years of the study. A, B and C-significant at $p \leq 0.01$.

The level of DON in winter wheat grains did not differ between years of the study (Table S2). The statistical analysis revealed no significant differences in the DON levels between locations representing different climatic regions (Figure 3A-C). In the first year of the study, the level of DON contamination was the highest in Sulejów $(224.35 \mu \mathrm{g} / \mathrm{g})$ and lowest in Ruska Wieś, Białogard and Tomaszów Bolesławicki at $32.47 \mu \mathrm{g} / \mathrm{g}, 57.15 \mu \mathrm{g} / \mathrm{g}$ and $21.18 \mu \mathrm{g} / \mathrm{g}$, respectively (Figure 3A). In the second year of the study, the amount of DON was the highest in the grain from Sulejów and lowest in the grains from Ruska Wieś, Kościelna Wieś and Białogard (Figure 3B). The average DON content of the wheat grains was lowest in Ruska Wieś belonging to region 5B (Figure 3C). 
A

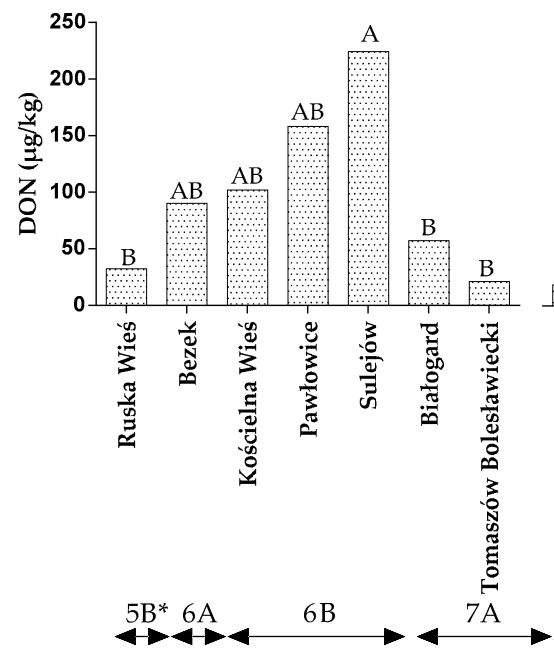

B

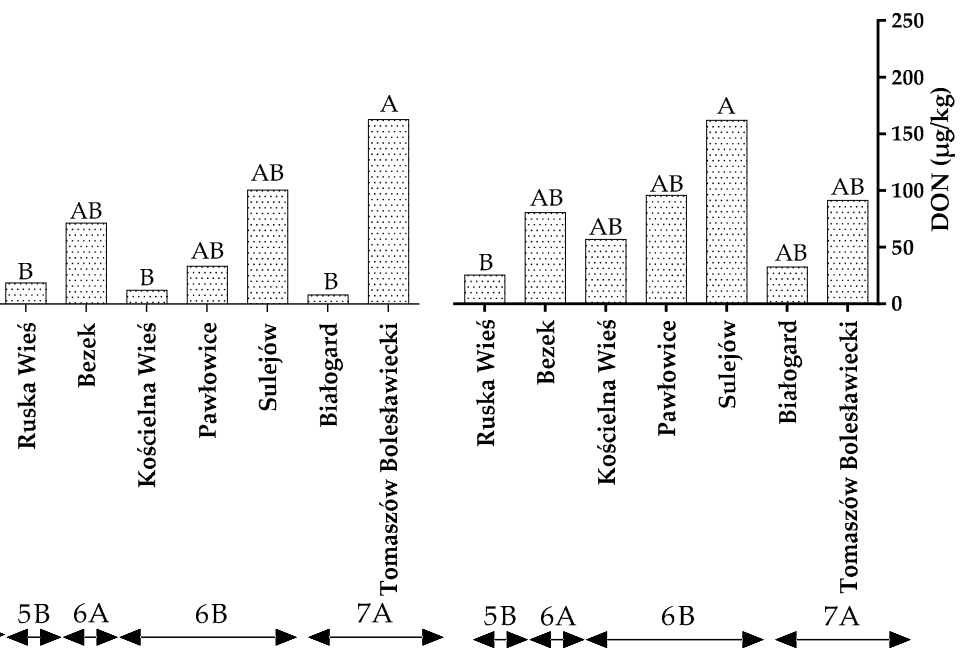

Figure 3. Quantity of DON in winter wheat grains grown in different locations in Poland (* climatic regions) (A) during 2015, (B) during 2016 and (C) the average over the years of the study. a, b and $c$ - significant at $p \leq 0.05 ; \mathrm{A}, \mathrm{B}$ and $\mathrm{C}$-significant at $p \leq 0.01$.

\subsection{DNA Quantification by $q P C R$ in Other Fungal Species}

A conventional mycological analysis revealed that winter wheat grains were colonized mainly by F. avenaceum, F. poae and Penicillium spp. These fungi synthesize various mycotoxins, and they can compete with DON producers. Therefore, a qPCR analysis was carried out to reliably evaluate the contamination of winter wheat grains caused by the above fungi. The statistical analysis demonstrated that the quantity of the DNA of the F. avenaceum/F. tricinctum genotype varied significantly across the years of the study, locations and climatic regions (Figure $4 \mathrm{~A}-\mathrm{C}$ and Table S2). The quantity of $F$. avenaceum/F. tricinctum DNA was the highest in Ruska Wieś located in region 5B (1885.9 pg), particularly in 2016.

A

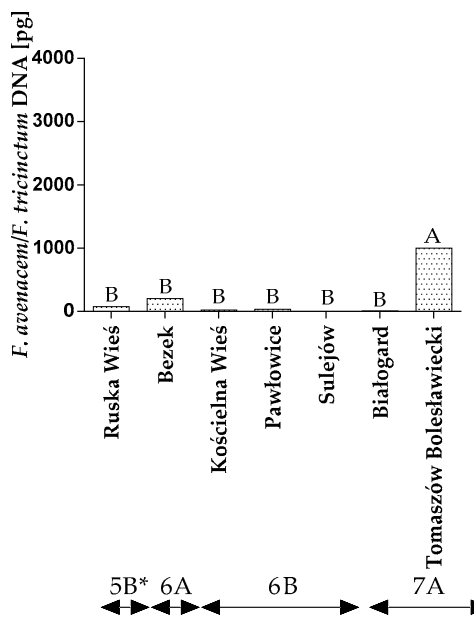

B

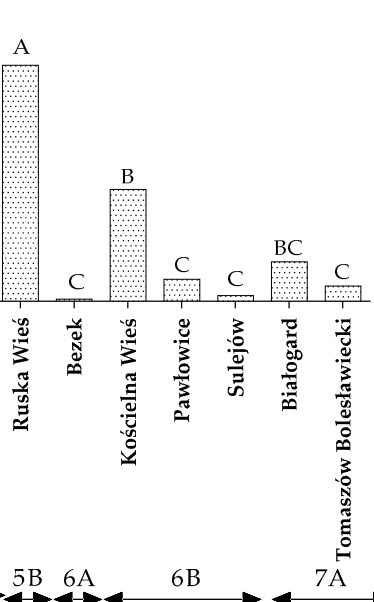

C

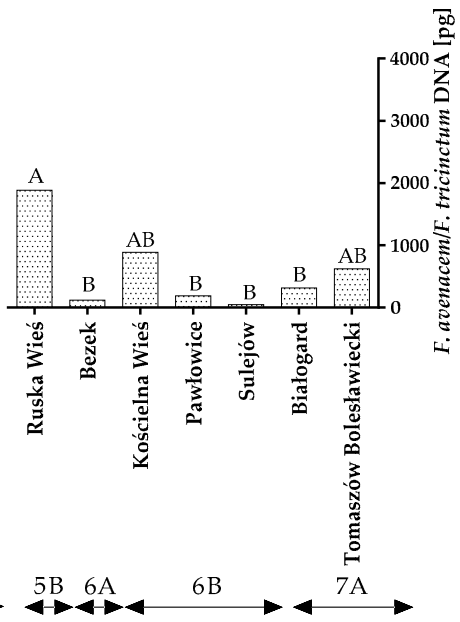

Figure 4. Quantity of F. avenaceum/F. tricinctum DNA (pg) in winter wheat grains grown in different locations in Poland (* climatic regions) (A) during 2015, (B) during 2016 and (C) the average over the years of the study. A, B and C-significant at $p \leq 0.01$.

Similar observations were made in an analysis of $F$. poae DNA. In this case, differences were observed between the years of the study, locations and climatic regions (Figure 5A-C and Table S2). However, no differences were found between locations within climate regions. 


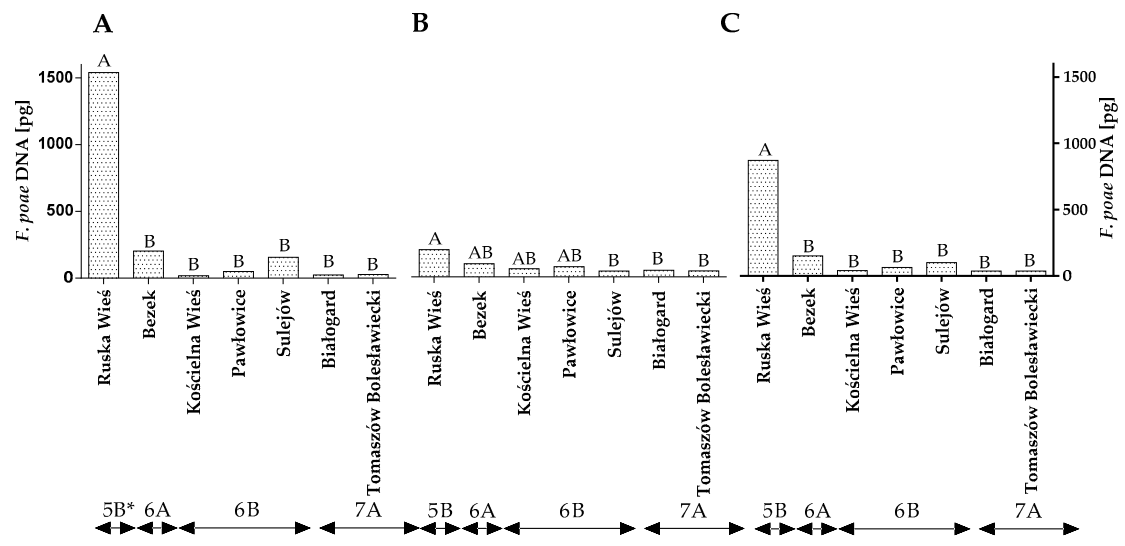

Figure 5. Quantity of F. poae DNA (pg) in winter wheat grains grown in different locations in Poland (* climatic regions) (A) during 2015, (B) during 2016 and (C) the average over the years of the study. A, B and C-significant at $p \leq 0.01$.

The qPCR analysis revealed that, in both years of the study, winter wheat grain grown in Ruska Wieś was more highly contaminated with F. poae DNA than grains from the remaining locations (Figure 5A,B). The average quantity of $F$. poae DNA in wheat grain from Ruska Wieś (climatic region 5B) was determined at 871.62 pg (Figure 5B). The analyzed parameter was significantly lower in the remaining locations/climatic regions.

The DNA of P. verrucosum, a major producer of ochratoxin A (OTA), was also quantified by qPCR. The statistical analysis demonstrated that the quantity of $P$. verrucosum DNA varied significantly across the years of the study, locations and climatic regions (Figure 6A-C and Table S2). Differences were also found between locations within the climate regions but only in the first year of the study (Figure 6A). The quantity of P. verrucosum DNA was highest in the grain samples from Ruska Wieś in the first year of the study (Figure 6A), whereas only trace amounts of $P$. verrucosum DNA were detected in the grain samples from Bezek (both years of the study) (Figure 6A,B). The statistical analysis confirmed that the climatic conditions of Ruska Wieś (region 5B) favored the development of P. verrucosum, whereas the average quantity of the DNA of this fungal species was significantly lower $(p<0.01)$ in the remaining locations/climatic regions (Figure 6C).

A

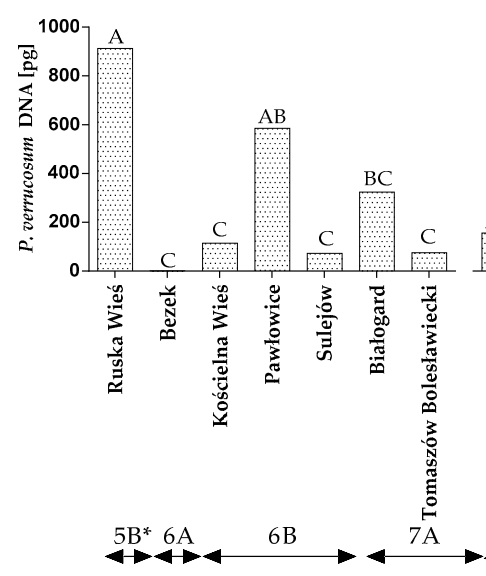

B

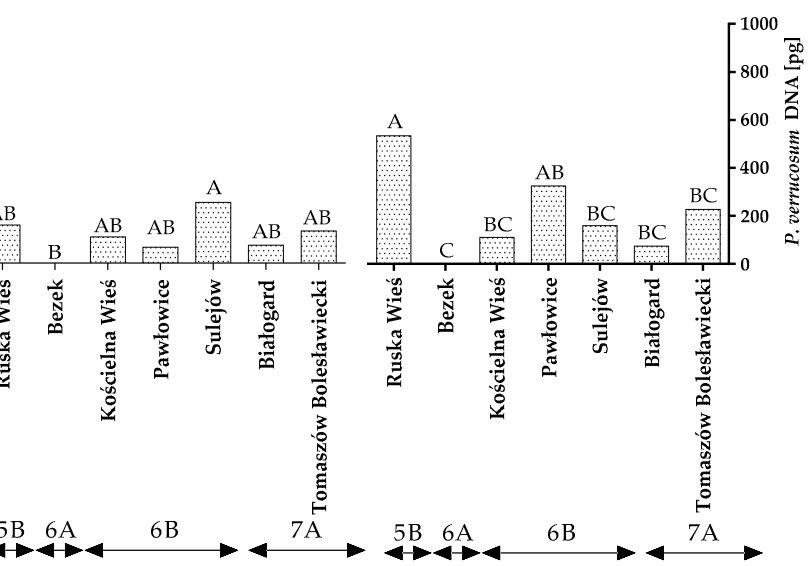

Figure 6. Quantity of P. verrucosum DNA (pg) in winter wheat grains grown in different locations in Poland (* climatic regions) (A) during 2015 (B) during 2016 and (C) the average over the years of the study. A, B and C-significant at $p \leq 0.01$.

\subsection{The Influence of Climate on the Prevalence of Fungi}

Spearman's rank correlation analysis revealed a significant positive correlation between the ambient temperature in the first ten days of May and the presence of the DNA of 
the F. avenaceum $/$ F. tricinctum genotype in winter wheat grains grown in Poland $(\mathrm{R}=0.54$; $p \leq 0.05$ ) (Table 2). The qPCR assay demonstrated that the F. avenaceum/F. tricinctum genotype was most prevalent in grains sampled from Ruska Wieś in 2016, when the mean daily temperature in the first ten days of May $\left(14.3^{\circ} \mathrm{C}\right)$ was higher than in the remaining locations (Table S3). In the remaining locations, the thermal conditions were less conducive to the spread of spike infections (temperatures of $10.9-13.5^{\circ} \mathrm{C}$ ).

Table 2. Correlation between temperature $\left({ }^{\circ} \mathrm{C}\right)$ and the quantity of fungal DNA in winter wheat grains (mean values for years of the study and locations).

\begin{tabular}{|c|c|c|c|c|c|c|c|}
\hline \multirow[b]{2}{*}{ Month } & \multirow[b]{2}{*}{ Days } & \multirow[b]{2}{*}{$\begin{array}{l}\text { F. avenaceum/ } \\
\text { F. tricinctum }\end{array}$} & \multicolumn{4}{|c|}{ DNA Quantity } & \multirow[b]{2}{*}{ DON $(\mu \mathrm{g} / \mathrm{kg})$} \\
\hline & & & F. culmorum & F. graminearum & F. poae & P. verrucosum & \\
\hline \multirow{3}{*}{ May } & $1-10$ & $0.54 *$ & -0.20 & -0.16 & -0.19 & -0.23 & -0.22 \\
\hline & $11-20$ & 0.09 & 0.18 & 0.31 & -0.22 & -0.30 & 0.18 \\
\hline & $21-31$ & 0.35 & -0.20 & -0.18 & -0.20 & -0.26 & -0.18 \\
\hline \multirow{3}{*}{ June } & $1-10$ & 0.06 & 0.19 & 0.18 & -0.09 & -0.28 & 0.16 \\
\hline & $11-20$ & 0.03 & 0.12 & 0.20 & -0.13 & -0.25 & 0.16 \\
\hline & $21-30$ & 0.33 & -0.15 & -0.19 & -0.23 & -0.30 & -0.14 \\
\hline \multirow{3}{*}{ July } & $1-10$ & -0.39 & 0.17 & 0.37 & 0.06 & -0.01 & 0.16 \\
\hline & $11-20$ & -0.07 & 0.21 & 0.35 & -0.30 & -0.29 & 0.26 \\
\hline & $21-31$ & 0.25 & 0.09 & 0.02 & -0.30 & -0.25 & 0.09 \\
\hline
\end{tabular}

${ }^{*} \mathrm{R}$-significant at $p \leq 0.05$.

The statistical analysis also revealed that the severity of F. avenaceum/F. tricinctum infection in winter wheat grains was significantly affected by the humidity between 11 and 20 May $(\mathrm{R}=0.50)$ (Table 3). In Ruska Wieś, the precipitation reached $42 \mathrm{~mm}$ between 11 and 20 May, and it could have contributed to the spread of FHB (Table S4).

Table 3. Correlation between precipitation levels $(\mathrm{mm})$ and the quantity of fungal DNA in winter wheat grains.

\begin{tabular}{|c|c|c|c|c|c|c|c|}
\hline \multirow[b]{2}{*}{ Month } & \multirow[b]{2}{*}{ Days } & \multicolumn{5}{|c|}{ DNA Quantity } & \multirow[b]{2}{*}{ DON $(\mu \mathrm{g} / \mathrm{kg})$} \\
\hline & & $\begin{array}{l}\text { F. avenaceum/ } \\
\text { F. tricinctum }\end{array}$ & F. culmorum & F. graminearum & F. poae & P. verrucosum & \\
\hline \multirow{3}{*}{ May } & $1-10$ & -0.02 & -0.04 & 0.09 & 0.25 & 0.18 & 0.08 \\
\hline & $11-20$ & $0.50 *$ & -0.21 & -0.23 & 0.02 & -0.10 & -0.25 \\
\hline & $21-31$ & -0.07 & -0.28 & 0.15 & -0.06 & -0.21 & 0.01 \\
\hline \multirow{3}{*}{ June } & $1-10$ & 0.09 & -0.20 & -0.13 & -0.24 & 0.02 & -0.06 \\
\hline & $11-20$ & 0.06 & -0.27 & 0.17 & -0.24 & -0.24 & 0.12 \\
\hline & $21-30$ & -0.22 & 0.08 & -0.22 & 0.01 & 0.17 & -0.18 \\
\hline \multirow{3}{*}{ July } & $1-10$ & 0.24 & -0.18 & -0.22 & -0.11 & -0.12 & -0.27 \\
\hline & $11-20$ & 0.12 & -0.16 & 0.06 & -0.26 & -0.15 & 0.13 \\
\hline & $21-31$ & -0.02 & -0.19 & -0.22 & 0.13 & 0.02 & -0.27 \\
\hline
\end{tabular}

${ }^{*} \mathrm{R}$-significant at $p \leq 0.05$.

The correlation analysis demonstrated that weather conditions had no significant effect on the prevalence of the remaining fungal species in winter wheat grains. However, the statistical analysis revealed certain noteworthy trends. High temperatures between 11 and 20 May promoted the occurrence of F. graminearum on wheat grains, which suggests that warm weather contributes to wheat infections caused by this fungal species. A detailed analysis of the effect of temperature on the prevalence of F. graminearum showed that, in the first year of the study, the quantity of F. graminearum DNA in wheat grains was highest in Sulejów (482.74 pg), where the average temperature between 11 and 20 May was $12.5^{\circ} \mathrm{C}$. The amount of the pathogen's DNA was somewhat lower in the grain samples from Bezek 
(256.42 pg) and Pawłowice (224.74 pg), where temperatures reached $13.0{ }^{\circ} \mathrm{C}$ and $12.6{ }^{\circ} \mathrm{C}$, respectively. In the second year of the study, the quantity of F. graminearum DNA was highest in the grain of wheat grown in Tomaszów Bolesławicki (334.06 pg), where the average temperature between 11 and 20 May was $12^{\circ} \mathrm{C}$. A mathematical analysis revealed no correlation between the quantity of F. graminearum DNA in the wheat grains and ten-day precipitation totals. A moderate positive correlation was observed between the ambient temperatures in the first twenty days of July and the content of F. graminearum DNA in the grains (Table 2). A detailed analysis revealed that, in both years of the study, air temperature of $19.8{ }^{\circ} \mathrm{C}$ promoted the spread of FHB infections (Table S3). Another interesting trend was also noted in July, when a minor negative correlation was observed between the temperature and the quantity of the DNA of the F. avenaceum/F. tricinctum genotype, which could suggest that $F$. avenaceum and $F$. graminearum have different temperature requirements or enter into competitive interactions. A Spearman's rank correlation analysis showed no effect of weather conditions on grain contamination with DON (Tables 2 and 3).

\subsection{Correlation between the Number of Fungal Isolates Identified by the Cultural Method and the} Quantity of the DNA of Fungal Species

The presence of correlations between the number of fungal isolates obtained from winter wheat grain and the quantity of the DNA of the analyzed fungal species/genotypes was also determined in the statistical analysis (Table 4). The analysis revealed a significant correlation between the number of F. avenaceum cultures and the quantity of the DNA of the F. avenaceum/F. tricinctum genotype measured in the $\mathrm{qPCR}$ assay ( $\mathrm{R}=0.49, p \leq 0.05)$.

Table 4. Correlation between the number of fungal isolates identified by the culture-based method and the DNA quantity determined by qPCR.

\begin{tabular}{lccccc}
\hline \multirow{2}{*}{ DNA Quantity } & \multicolumn{5}{c}{ Number of Isolates } \\
\cline { 2 - 6 } & F. avenaceum & F. tricinctum & F. culmorum & F. graminearum & P. verrucosum \\
\hline F. avenaceum/F. tricinctum & $0.49^{*}$ & 0.26 & 0.15 & -0.11 & -0.19 \\
F. culmorum & -0.32 & -0.17 & 0.27 & -0.04 & 0.11 \\
F. graminearum & -0.30 & 0.07 & 0.11 & -0.15 & -0.06 \\
F. poae & 0.00 & 0.18 & -0.25 & 0.17 & -0.22 \\
P. verrucosum & 0.01 & 0.02 & -0.06 & 0.18 & 0.03 \\
\hline
\end{tabular}

${ }^{*} \mathrm{R}$-significant at $p \leq 0.05$.

A higher number F. avenaceum cultures tended to be negatively correlated with the quantity of the DNA of DON-producing F. culmorum and F. graminearum $(\mathrm{R}=-0.32$ and $\mathrm{R}=-0.30$, respectively). An analysis of the remaining Fusarium species did not reveal significant correlations due to a smaller number of fungal isolates identified by the culturebased method.

The correlations between the quantity of the DNA of the analyzed fungal species/genotypes and DON levels in the winter wheat grains were also determined in the statistical analysis (Table 5).

Table 5. Correlation between the quantity of fungal DNA determined by qPCR and DON levels in winter wheat grains.

\begin{tabular}{lccccc}
\hline \multirow{2}{*}{ DNA Quantity } & \multicolumn{2}{c}{ qPCR Detection (DNA) } & \multicolumn{2}{c}{ DON $(\boldsymbol{\mu g} / \mathbf{k g})$} \\
\cline { 2 - 5 } & F.culmorum & F. graminearum & F. poae & P. verrucosum & \\
\hline F. avenaceum /F. tricinctum & $-0.49^{*}$ & $-0.59 *$ & -0.04 & -0.03 & $-0.58^{*}$ \\
F. culmorum & - & 0.32 & -0.09 & 0.13 & $0.51^{*}$ \\
F. graminearum & - & - & -0.11 & -0.09 & $0.89 *$ \\
F. poae & - & - & - & 0.09 & -0.14 \\
P. verrucosum & - & - & - & - & -0.01 \\
\hline
\end{tabular}

${ }^{*} \mathrm{R}$-significant at $p \leq 0.05 ;{ }^{* *} \mathrm{R}$-significant at $p \leq 0.01$. 
A mathematical analysis revealed a negative correlation between the quantity of F. avenaceum /F. tricinctum DNA and DON levels in winter wheat grains $(\mathrm{R}=-0.58 ; p \leq 0.05)$. The deoxynivalenol levels were also significantly correlated with the quantity of the DNA of the DON-producing fungi F. culmorum and F. graminearum (Table 5). A Spearman's rank correlation analysis demonstrated significant correlations between the quantity of the DNA of the F. avenaceum/F. tricinctum genotype and the DNA of F. culmorum and F. graminearum $(\mathrm{R}=-0.49$ and $\mathrm{R}=-0.59$, respectively; $p \leq 0.05)$ (Table 5).

\section{Discussion}

The presence of mycotoxins in food products is not only a serious economic problem, but it also poses a health risk for humans and animals around the world. The occurrence of mycotoxins in agricultural crops is influenced by the local climate [32,33]. Extreme temperatures, drought, high humidity and some agricultural practices can contribute to food and feed contamination with mycotoxins [34]. Inadequate grain storage can lead to the accumulation of mycotoxins, which are responsible for up to $50 \%$ of cereal production losses worldwide [6]. FHB reduces the quantity and quality of wheat yields through the selective loss of albumin, gluten proteins and starch in grains [35]. In recent years, the geographic distribution of various toxin-producing fungal species has changed due to extreme weather events [6]. High temperatures, high relative humidity $(>70 \%)$ and/or high precipitation during the heading and flowering stages contribute to fungal epidemics in wheat stands [36].

In the present study, the grains of the analyzed winter wheat varieties were colonized mainly by F. avenaceum and F. poae, as well as by F. culmorum, F. equiseti, F. graminearum, F. oxysporum, F. sambucinum, F. solani, F. sporotrichioides and F. tricinctum. According to the research, the predominant causal agents of FHB can change over time [37], but F. graminearum and F. culmorum are considered to be the most common $[6,27,38]$.

The results of the mycological analysis and qPCR confirmed that the wheat grain was weakly colonized by F. culmorum. The analyzed grain was most abundantly colonized by F. avenaceum and F. poae, followed by F. graminearum. Penicillium verrucosum DNA was also identified in the wheat grain, in particular in cold climatic region $5 \mathrm{~B}$, which is consistent with the literature, because this species typically occurs in cold regions [6].

Pathogenic fungal species produce mycotoxins that, under favorable weather conditions, can be accumulated in grains directly after infection. This group of compounds includes DON, which is one of the most frequently identified mycotoxins in crops and plant-based foods in Poland [39]. In this study, DON was detected in all the samples of winter wheat grains within a concentration range of $4.00-311 \mu \mathrm{g} / \mathrm{kg}$. In the literature, DON has been identified in winter wheat grains at a concentration of $127.95 \mu \mathrm{g} / \mathrm{kg}$ [37]. A four-year study demonstrated that the DON levels in wheat grains cultivated in Poland were generally low and did not exceed $1250 \mu \mathrm{g} / \mathrm{kg}$, which suggests that the produced grain was safe for human and animal consumption [1]. In another study, DON was the most frequently identified mycotoxin in samples of wheat grains [40]. The cited authors detected DON in 92\% of the grain samples in $2017(5.2-1670.7 \mu \mathrm{g} / \mathrm{kg})$ and in $61 \%$ of the samples in $2018(95.0-461.7 \mu \mathrm{g} / \mathrm{kg})$. According to the research, DON is a ubiquitous toxin in the temperate climate [41], as well as in other climatic zones [42-45]. In a study investigating wheat grain grown in Tunisia, $83 \%$ of the analyzed samples were contaminated with DON [42]. This toxin was also detected in other cereals cultivated in Africa, Asia and America [43]. A study conducted in Uruguay in 1993-1995 revealed the presence of DON in wheat grain and other crops [44]. High concentrations of DON in wheat were also reported in Japan [45].

In the present study, the DON levels in the grain samples differed across the examined locations and climatic regions. On average, the DON concentration was the highest in the wheat grain grown in Sulejów $[162 \mu \mathrm{g} / \mathrm{kg}$ ] and the lowest in the samples obtained from Ruska Wieś [25.4 $\mu \mathrm{g} / \mathrm{kg}$ ]. Mathematical analyses confirmed that grain contamination with DON was directly associated with the severity of F. graminearum and F. culmorum infections. 
The quantity of F. culmorum and F. graminearum DNA was correlated with the DON levels in the examined grain samples, as demonstrated by the calculated correlation coefficients $(\mathrm{R}=0.51$ at $p=0.05$ and $\mathrm{R}=0.89$ at $p=0.01$, respectively). The concentration of $\mathrm{DON}$ at the site of infection may be reduced as a result of transport by xylem to other plant tissues [46]. Moreover, trichothecenes undergo glycosylation, and mycotoxins can be masked in conventional chemical analyses [47]. Even high levels of grain contamination with mycotoxins are not always directly correlated with the severity of the FHB symptoms [6].

The presence of a correlation between the DON levels and the concentration of the DNA of trichothecene-producing fungi was previously confirmed in a study of qPCR detection of toxin-producing fungi in pig feed [11]. In the current study, an analysis of the correlations between DON levels and the concentrations of F. avenaceum/F. tricinctum DNA demonstrated that DON-producing fungi enter into competitive interactions with the F. avenaceum $/ F$. tricinctum genotype $(\mathrm{R}=-0.58$ at $p=0.05)$. Moreover, the Spearman's rank correlation coefficients point to the presence of negative correlations between the quantity of the DNA of F. culmorum and F. graminearum vs. the F. avenaceum/F. tricinctum genotype $(\mathrm{R}=-0.49$ and $\mathrm{R}=-0.59$, respectively; $p=0.05)$. Weak negative correlations were also noted between the quantity of F. graminearum and F. culmorum DNA in the grain and the number of $F$. avenaceum cultures, which could be indicative of competitive interactions in spikes that had been previously infected with F. avenaceum. Fusarium species that cause FHB to enter into synergistic or competitive interactions. A population study examining the fungal complex causing FHB revealed positive correlations between F. avenaceum and F. culmorum coinfecting wheat spikes and the absence of such correlations between F. avenaceum and F. graminearum [48]. However, according to the cited authors, these observations could be attributed to fungal responses to environmental conditions rather than synergy effects. The presence of competitive interactions between Fusarium species was postulated in earlier studies, but further research focusing on specific toxin-producing strains is needed to confirm these findings [49]. The isolates of F. graminearum and F. avenaceum have different mycotoxin profiles. Fusarium graminearum produces trichothecenes, whereas F. avenaceum synthesizes enniatins (ENNs) [50]. According to the latest research, the toxins produced by F. avenaceum and F. graminearum can coinfect wheat plants, but their effects differ [51]. The synergistic activity of DON and ENNs compromises seed germination and plant growth and leads to chlorophyll degradation, but these mycotoxins enter into antagonistic interactions in cell death and the induction of oxidative stress, where DON counteracts the cellular stress produced by ENB. An in vitro study also revealed that ENNs inhibited F. graminearum development, whereas DON promoted the growth of F. avenaceum, which suggests that ENNs participate in competitive interactions between fungi. This hypothesis was confirmed by an earlier study that demonstrated that the accumulation of ENNs was unrelated to the severity of the disease symptoms in potatoes, peas and durum wheat (FHB) [52].

DON and ENNs could play different roles in the infection of cereal crops by Fusarium fungi that synthesize these mycotoxins. DON participates in the infection process and is directly responsible for the symptoms of necrosis and, whereas ENNs do not exert such effects and can be responsible for the effective colonization of plant tissues. However, high concentrations of F. avenaceum DNA could be attributed to weather conditions that promote infection. In the present study, in wheat grain samples from Ruska Wieś, F. avenaceum DNA was detected mainly in 2016, which was characterized by the highest mean daily temperature recorded in Poland in the first ten days of May (which could be considered anomaly), as well as a relative high humidity between 11 and 20 May. According to the literature, growing greenhouse gas emissions lead to changes in the regional climate patterns and cause seasonal variations that are often extreme. The steady increase in the mean daily temperatures is accompanied by sudden and highly abundant precipitation but also catastrophic drought events [18]. The causal agents of FHB, i.e., F. avenaceum, F. culmorum, F. graminearum and F. poae, have different temperature preferences, and selected species can become locally dominant during extreme weather events. These effects can be 
exacerbated by different toxicogenic potentials of fungal species and strains, which are not always synergistic.

Fusarium avenaceum is a major pathogen of crops that causes significant economic losses around the world [53]. Spike infections with F. avenaceum can decrease grain yields by up to $25 \%$ [54]. This cosmopolitan fungal species can be established as a saprotroph in the soil environment, but it can also infect plants both as a weak and a dominant pathogen [55]. Fusarium avenaceum has a wide range of host plant species, and it has been identified as the causal agent of crop infections in the USA, Northern and Central Europe, Australia, South Africa and the arctic and subarctic, as well as in the cold regions of Finland, Norway, Siberia and Canada $[53,56]$.

In many cases, the weather conditions determine the progression and spread of FHB [57]. Excessive precipitation, high humidity and high temperatures during wheat flowering and in the early stages of grain development (watery ripe/early milk) contribute to the development and spread of Fusarium infections [58]. In the current study, the quantity of the DNA of the F. avenaceum/F. tricinctum genotype was positively correlated with the mean daily temperature in the first ten days of May $(\mathrm{R}=0.54, p=0.05)$ and with the total precipitation between 11 and 20 July $(R=0.50, p=0.05)$, which confirmed that weather conditions influence grain colonization by the causal agents of FHB.

The severity of disease symptoms and toxin accumulation can vary across different stages of plant growth [36]. Spikes become infected during flowering, when ascospores are released from perithecia and transported by wind and raindrops [59]. Weeds and other crops can also act as a source of infection [60,61]. Infections that occur in the earlier stages of wheat growth are unlikely to be associated with FHB, although Fusarium fungi also cause necrosis and dry rot of the basal stem and crown tissue, also known as Fusarium crown rot (FCR), of wheat [5]. According to the literature, F. graminearum can also infect wheat nodes, but such observations have been rarely made and only in highly susceptible varieties and/or during wet weather [62]. Some authors have argued that infected seedlings do not play a role in the progression of FHB [6], whereas other researchers have concluded that the inoculum from infected seedlings can accumulate on leaves and lead to an outbreak of infection in the flowering stage [61]. In such a case, conidia could also be a source of infection, but they play a less important role in the development of FHB than ascospores, because they are produced under humid and warm conditions and are carried by the wind over much shorter distances [63].

There is considerable evidence to indicate that temperature and humidity are the main environmental factors responsible for the progression of FHB [2,57,64]. The severity of the spike infection caused by F. avenaceum increased in response to high precipitation [65]. Other authors found that the concentration of F. poae gDNA in wheat grains was influenced by the weather conditions in May and June when cereals develop symptoms of FHB [12]. A positive correlation was also reported between the precipitation levels in May and the concentration of F. poae DNA in wheat grains $(\mathrm{R}=0.75)[66]$.

$\mathrm{Xu}$ et al. [67] reported that both the severity of FHB symptoms and mycotoxin concentrations in wheat grains increased with the duration of wetness and increasing temperatures. Mycotoxin production was also greatly enhanced by high temperatures $\left(\geq 20^{\circ} \mathrm{C}\right)$ during the initial infection periods. According to the literature, F. graminearum infects spikes at higher temperatures (optimal temperature: $26-28{ }^{\circ} \mathrm{C}$; water activity: 0.88 ) than F. culmorum, which thrives at a temperature of $21^{\circ} \mathrm{C}$ and water activity of 0.87 [24]. In another study, the hyphal growth of all strains of F. graminerum was significantly inhibited, the metabolism was slowed down and the accumulation of DON decreased at a temperature of $10^{\circ} \mathrm{C}$ [68].

In the present study, the weather conditions had no significant effect on the quantity of F. culmorum and F. graminearum DNA. However, the smaller number of F. culmorum cultures and the smaller quantity of F. culmorum DNA identified by qPCR in comparison with F. graminearum confirmed the trends reported in other studies and indicated that climate change has shifted the geographic distribution of F. graminearum to Northern and Central Europe, which were previously dominated by F. culmorum [26]. 
Wenda-Piesik et al. [69] found that a total monthly rainfall of $113.9 \mathrm{~mm}$ and a relatively low air temperature in June (monthly average of $15.5^{\circ} \mathrm{C}$ ) resulted in the highest severity of FHB. In Poland, wheat anthesis extends to June, which is believed to be most critical for FHB development [70]. The findings of the above authors [69] seem to confirm the results of this study, where, in the first year, the mean monthly temperatures in June ranged from 15.0 to $15.6^{\circ} \mathrm{C}$ in Tomaszów Bolesławicki and Kościelna Wieś, contributing to very high amounts of Fusarium DNA in the wheat grains. The predominant species in the above locations were F. poae and F. avenaceum. In the second year, the mean monthly temperatures in June were considerably higher (the average temperature in all locations reached $17.6^{\circ} \mathrm{C}$, compared with $15.9^{\circ} \mathrm{C}$ in 2015). In 2016, the quantity of F. avenaceum DNA increased five-fold due to an increase in temperature, whereas the DNA of F. poae, which tends to prefer cooler regions, decreased 3.5 times. The quantity of F. graminearum DNA in the wheat grains also varied across the years of the study. In the first year, the quantity F. graminearum DNA was the highest in Sulejów, Bezek and Pawłowice, characterized by high average temperatures in June $\left(16.1,17.5\right.$ and $17.1^{\circ} \mathrm{C}$, respectively). In the second year, the quantity F. graminearum DNA was the highest in Tomaszów Bolesławicki, where the average temperature in June reached $17.1^{\circ} \mathrm{C}$, while higher temperatures were noted in the remaining locations. It should be stressed that the present findings do not fully explain the relationship between air temperature and wheat grain colonization by Fusarium fungi, because individual species can be represented by cold-tolerant strains [68].

Precipitation affects the development of FHB in two ways. High humidity contributes to the onset of infection, and spores are washed off from plant surfaces by rain in its later stages [71]. Abundant but sporadic rainfall can also intensify the symptoms of FHB, because raindrops can carry Fusarium spores from the soil inoculum [72]. Precipitation can also reduce the efficacy of fungicides, depending on its frequency after treatment [73]. In another study, the response of the grain yield to fungicide application was significantly influenced by rainfall in May and June [57]. The cited authors concluded that fungicide treatments against FHB are justified when the precipitation levels are high during the flowering and heading stages.

In this study, the DON levels differed in the grain samples collected from various locations/climatic regions. On average, the DON concentration was highest in the wheat grains grown in Sulejów $(162 \mu \mathrm{g} / \mathrm{kg})$ and lowest in the grain samples from Ruska Wieś $(25.4 \mu \mathrm{g} / \mathrm{kg})$ in climatic region 5B. These results are consistent with the findings of other authors who have demonstrated that weather conditions affected the DON levels in wheat grains grown in Poland [40]. In the cited study, the DON concentrations were significantly higher in wheat grains grown in Southern compared to Northern Poland, which was confirmed by this research because climatic region 5B occupies Northeastern Poland. According to the cited authors, the dry and hot summer of 2018 not only decreased the wheat yields but also inhibited the development of Fusarium pathogens, which is why the mycotoxin levels were low in the analyzed grains [40]. However, an earlier study conducted by the same researchers produced contrary results, and the mycotoxin levels were highest in the grains grown in Northeastern Poland, where the concentration of DON peaked at $1264.5 \mu \mathrm{g} / \mathrm{kg}$. The observed differences in the grain contamination levels were attributed mainly to weather conditions [74]. In another experiment, DON was identified in nearly all the grain samples, and the DON concentration was highest $(2265 \mu \mathrm{g} / \mathrm{kg})$ in a year characterized by high precipitation during the growing season [41]. In the present study, weather conditions had no effect on the presence of the DNA of DON-producing fungi or DON itself in the grains, which could be attributed to a relatively low grain contamination with F. graminearum and F. culmorum and high contamination with F. poae and F. avenaceum. However, climate change undoubtedly affects the prevalence of fungal species that cause FHB, and further research is needed to evaluate the impact of climate change on the populations of pathogenic fungi and the mycotoxin levels in cereal grains. 


\section{Conclusions}

1. Fusarium avenaceum and F. graminearum were the predominant fungal species in the winter wheat grains cultivated in most of the analyzed locations in Poland.

2. The prevalence of fungal pathogens was influenced by weather conditions during the growing season of winter wheat, and DON-producing species were predominant in climatic regions $6 \mathrm{~A}$ and $6 \mathrm{~B}$, which also contributed to higher grain contamination with DON.

3. Fusarium avenaceum, F. poae and P. verrucosum were the predominant species in the winter wheat grains grown in the coldest climatic region.

4. Mathematical analyses revealed a positive correlation between the quantity of F. avenaceum DNA (pg) and temperatures $\left({ }^{\circ} \mathrm{C}\right)$ in the first ten days of May, as well as humidity $(\mathrm{mm})$ between 11 and 20 May.

5. Spearman's rank correlation analysis confirmed the presence of competitive interactions between enniatin-producing F. avenaceum and DON-producing F. culmorum and F. graminearum.

6. A positive correlation was observed between the presence of F. culmorum and F. graminearum DNA and DON contamination of winter wheat grains.

\section{Materials and Methods}

\subsection{Field Experiment}

The study involved field experiments that were carried out between 2014 and 2016 in the Experimental Stations for the Evaluation of Crop Varieties (SDOO) in different climatic regions in Poland, consistent with the European climate zones: SDOO Białogard, SDOO Bezek, SDOO Kościelna Wieś, SDOO Ruska Wieś, SDOO Sulejów, SDOO Tomaszów Bolesławiecki and SDOO Pawłowice (Table 6 and Figure S1).

Table 6. Climatic regions in Poland [19].

\begin{tabular}{lcc}
\hline \multicolumn{1}{c}{ Location } & GPS & Climatic Region \\
\hline Białogard & $\varphi=54^{\circ} 00^{\prime}, \lambda=16^{\circ} 00^{\prime}, \mathrm{H}=24 \mathrm{~m}$ a.s.l. & $7 \mathrm{~A}$ \\
Bezek & $\varphi=51^{\circ} 11^{\prime}, \lambda=23^{\circ} 15^{\prime}, \mathrm{H}=224 \mathrm{~m}$ a.s.l. & $6 \mathrm{~A}$ \\
Kościelna Wieś & $\varphi=51^{\circ} 48^{\prime}, \lambda=18^{\circ} 01^{\prime}, \mathrm{H}=120 \mathrm{~m}$ a.s.l. & $6 \mathrm{~B}$ \\
Ruska Wieś & $\varphi=53^{\circ} 53^{\prime}, \lambda=22^{\circ} 28^{\prime}, \mathrm{H}=130 \mathrm{~m}$ a.s.l. & $5 \mathrm{~B}$ \\
Sulejów & $\varphi=51^{\circ} 35^{\prime}, \lambda=19^{\circ} 86^{\prime}, \mathrm{H}=188 \mathrm{~m}$ a.s.l. & $6 \mathrm{~B}$ \\
Tomaszów Bolesławiecki & $\varphi=51^{\circ} 17^{\prime}, \lambda=15^{\circ} 41^{\prime}, \mathrm{H}=200 \mathrm{~m}$ a.s.l. & $7 \mathrm{~A}$ \\
Pawłowice & $\varphi=50^{\circ} 28^{\prime}, \lambda=18^{\circ} 29^{\prime}, \mathrm{H}=240 \mathrm{~m}$ a.s.l. & $6 \mathrm{~B}$ \\
\hline
\end{tabular}

$\varphi$-latitude, $\lambda$-longitude and $\mathrm{H}-$ meters above sea level.

The grains of winter wheat var. Artist and Kilimanjaro (characterized by different winter hardiness and resistance to FHB; Artist - moderate resistance; RGT Kilimanjarorelatively high resistance) were randomly sampled. Ten grain samples collected from each analyzed location were pooled into composite samples of $1 \mathrm{~kg}$. Wheat grain samples were taken in accordance with ISO 24333 [75]. The samples were analyzed in the laboratory of the Department of Entomology, Phytopathology and Molecular Diagnostics of the University of Warmia and Mazury in Olsztyn.

\subsection{Isolation and Identification of Fungi by the Culture-Based Method}

The taxonomic composition of fungal communities colonizing wheat grains was determined in the first stage of the study. One hundred kernels were selected randomly from each sample and were rinsed with distilled water, rinsed with $70 \%$ ethanol for $5 \mathrm{~min}$ and with $1 \%$ sodium hypochlorite $(\mathrm{NaOCl})$ solution for 5 min and rinsed three times with sterile distilled water. The prepared specimens were placed on PDA in Petri dishes (7 kernels per dish) and incubated at a temperature of $20-23^{\circ} \mathrm{C}$ for $7-10$ days under laboratory conditions. Next, fragments of the emerged mycelia were transferred onto fresh PDA in sterile Petri dishes. After 14-20 days, the emerged fungal colonies were 
examined under an optical microscope and identified to the genus and species levels based on morphological traits, taxonomic keys and monographs [55,76,77].

\subsection{Extraction and Quantification of Genomic DNA from Fusarium fungi Colonizing Winter} Wheat Grain

DNA was isolated from winter wheat grains with the Maxwell 16 instrument and Maxwell 16 DNA Purification Kit (Promega, Madison, WI, USA). Randomly selected grain samples of $20 \mathrm{~g}$ each (in three biological replicates) were ground in the IKA A11 Basic Analytical mill (IKA-Werke, Staufen, Germany) and then in a mortar filled with liquid nitrogen for $45 \mathrm{~s}$. Ground grains were transferred to 1.5-mL Eppendorf tubes, and CTAB extraction buffer and RNase A (Promega) were added. The samples were incubated for $30 \mathrm{~min}$ in a thermomixer (Eppendorf, Hamburg, Germany). DNA was extracted with the Maxwell 16 instrument according to the manufacturer's instructions. The purity and quantity of the isolated DNA were determined with the NanoDrop 2000C spectrophotometer (Thermo Scientific, Waltham, MA, USA). The extracted DNA was stored at a temperature of $4{ }^{\circ} \mathrm{C}$ until further analysis.

\subsection{Identification of Selected Fusarium Species and P. verrucosum by qPCR}

A quantitative qPCR method was used to assess the presence of DNA from the selected fungal species. The isolated gDNA was used as the matrix in real-time PCR. qPCR was conducted in the ABI 7500 FAST system (Applied Biosystems, Waltham, MA, USA) with the use of Applied Biosystems reagents, specific primers and probes (Table 7) based on the protocols for the analyzed fungal species. The reaction mix of $25 \mu \mathrm{L}$ contained: $12.5 \mu \mathrm{L}$ of the TaqMan Universal PCR Master Mix (Applied Biosystems, USA), 10 pM of each primer, $10 \mathrm{pM}$ of each primer labeled with FAM at the $5^{\prime}$ and $6^{\prime}$ ends and TAMRA quencher at the $3^{\prime}$ end, $4.5 \mu \mathrm{L}$ of deionized water and $5 \mu \mathrm{L}$ of DNA. The amplification conditions were as follows: initial denaturation at $95^{\circ} \mathrm{C}$ for $5 \mathrm{~min}$, followed by 40 cycles of denaturation at $95^{\circ} \mathrm{C}$ for $15 \mathrm{~s}$, primer annealing at $60{ }^{\circ} \mathrm{C}$ for $15 \mathrm{~s}$ and strand synthesis at $72{ }^{\circ} \mathrm{C}$ for $1 \mathrm{~min}$. The quantity of DNA isolated from each fungal species and genotype was calculated with the use of calibration curves (Table 7) and the methods described by Livak and Schmittgen [78] and Pfaffl [79] with some modifications.

Table 7. qPCR primers and probes used in the identification of Fusarium species and P. verrucosum.

\begin{tabular}{|c|c|c|c|c|}
\hline Genotype/Gene & Primer/Probe & Sequence $\left(5^{\prime}-3^{\prime}\right)$ & $\begin{array}{c}\text { Regression } \\
\text { Equation, Efficiency } \\
\text { of qPCR (E) }\end{array}$ & References \\
\hline $\begin{array}{l}\text { F. avenaceum/ } \\
\text { F. tricinctum } \\
\text { Esyn1 }\end{array}$ & $\begin{array}{c}\text { Avetric } \mathrm{f} \\
\text { Avetric } \mathrm{r} \\
\text { Avetric probe }\end{array}$ & $\begin{array}{c}\text { 5'-AGCAGTCGAGTTCGTCAACAGA-3' } \\
\text { 5'-GGCYTTTCCTGCGAACTTG-3' } \\
\text { FAM-CCGTCGAGTCCTCT-MGB }\end{array}$ & $\begin{array}{c}y=-3.35 x+37.21 \\
E=98.5 \\
R^{2}=0.99\end{array}$ & [80] \\
\hline $\begin{array}{l}\text { F. culmorum } \\
\qquad E F 1 \alpha\end{array}$ & $\begin{array}{l}\text { FculC561 fwd } \\
\text { FculC614 rev }\end{array}$ & $\begin{array}{c}\text { 5'-CACCGTCATTGGTATGTTGTCACT-3' } \\
\text { 5'-CGGGAGCGTCTGATAGTCG-3' }\end{array}$ & $\begin{array}{c}y=-3.49 x+35.45 \\
E=93.6 \\
R^{2}=0.98\end{array}$ & [81] \\
\hline $\begin{array}{l}\text { F. graminearum } \\
\qquad \text { EF1 } 1 \alpha\end{array}$ & $\begin{array}{l}\text { FgramB379 fwd } \\
\text { FgramB411 rev }\end{array}$ & $\begin{array}{c}\text { 5'-CCATTCCCTGGGCGCT-3' }^{\prime} \\
\text { 5'-CCTATTGACAGGTGGTTAGTGACTGG-3' }^{\prime}\end{array}$ & $\begin{array}{c}y=-3.29 x+33.32 \\
E=100 \\
R^{2}=0.97\end{array}$ & [81] \\
\hline $\begin{array}{l}\text { F. poae } \\
\text { Esyn1 }\end{array}$ & $\begin{array}{c}\text { Poae } f \\
\text { Poae } r \\
\text { Poae probe }\end{array}$ & $\begin{array}{c}\text { 5'-GCGGCCGCTTTTGTCA-3' }^{\prime} \\
\text { 5'-GCCTTTCCAGCAAGAGATGGT-3' }^{\prime} \\
\text { FAM-AAAGCGGTCGAGTCTG-MGB }\end{array}$ & $\begin{array}{c}\mathrm{y}=-3.2 \mathrm{x}+33.85 \\
\mathrm{E}=99.8 \\
\mathrm{R}^{2}=0.99\end{array}$ & [80] \\
\hline $\begin{array}{l}\text { P. verrucosum } \\
\text { rRNA }\end{array}$ & $\begin{array}{l}\text { rRNA forward } \\
\text { rRNA reverse } \\
\text { PV rRNA-Probe }\end{array}$ & $\begin{array}{c}\text { 5'-TAAGGTGCCGGAATACACGCTCAT-3' } \\
\text { 5'-TAGTTCATTCGGCCCGTGAGTTGT-3' } \\
\text { Fam-TCTAGACAGCCCGACGGTGGCCATGGAAGT- } \\
\text { Tamra }\end{array}$ & $\begin{array}{c}\mathrm{y}=-3.53 \mathrm{x}+22.27 \\
\mathrm{E}=92.7 \\
\mathrm{R}^{2}=0.99\end{array}$ & [82] \\
\hline
\end{tabular}




\subsection{Detection and Quantification of DON}

Samples of ground grains of $25 \mathrm{~g}$ each (in three replicates) were placed in 250-mL conical flasks. The samples were extracted in $200 \mathrm{~mL}$ of deionized water by shaking on a mechanical shaker for $1 \mathrm{~h}$. The extracts were filtered and purified on an IAC column. The samples were transferred to affinity columns with the DONtest WB kit (VICAM, Milford, MA, USA). The extract was passed through affinity columns, and the columns were washed with $5 \mathrm{~mL}$ of deionized water. The eluate was collected into a glass tube, and the solvent was evaporated in a stream of nitrogen. The residue was dissolved in the mobile phase $(0.5 \mathrm{~mL})$ for the HPLC assay, and it was shaken on a mechanical shaker. The extracts were subjected to a chromatographic analysis in the Shimadzu LC-20AD system (Tokyo, Japan) under the following conditions: chromatographic column-Jupiter $5 \mathrm{u} \mathrm{C18} \mathrm{300A}$ (Phenomenex, Torrance, CA, USA), $250 \times 4.60 \mathrm{~mm}$; column temperature $-24{ }^{\circ} \mathrm{C}$; mobile phase-water:acetonitrile $(900 \mathrm{~mL}: 100 \mathrm{~mL})$; flow rate-1 $\mathrm{mL} / \mathrm{min}$; injection volume$100 \mu \mathrm{L}$ and UV detector, wavelength $-220 \mathrm{~nm}$. The concentrations of DON were determined by correlating the peak areas of the samples with the standard curve obtained by HPLC analysis of the standard solution. The limit of quantification of the method used was $\mathrm{LOQ}=10 \mu \mathrm{g} / \mathrm{kg}$, the repeatability expressed as the coefficient of variation was $<10 \%$ and the accuracy expressed as recovery exceeded $93 \%$.

\subsection{Statistical Analysis}

Data were processed statistically in Dell Statistica v. 13 (software.dell.com, accessed on 31 November 2021). The significance of the differences between the average gDNA yield of each fungal species was evaluated with Tukey's HSD test at $p=0.01$. The strength of the associations between the examined variables was determined by calculating the values of the Spearman's rank correlation coefficients $(R)$.

Supplementary Materials: The following are available online at https:/ / www.mdpi.com/article/ 10.3390/toxins14020102/s1: Table S1. Fungi isolated from winter wheat grains. Table S2. Results of qPCR detection of fungal DNA and DON contamination in wheat grains across the locations and years of the study. Table S3. Mean ten-day air temperatures in 2014-2016 $\left({ }^{\circ} \mathrm{C}\right)$ across locations ( ${ }^{*}$ climatic regions). Table S4. Ten-day precipitation totals in $2014-2016\left({ }^{\circ} \mathrm{C}\right)$ across locations (* climatic regions). Figure S1. Map of Poland, including specific locations and climatic regions $\left(7 \mathrm{~B}^{*}\right.$ zone not represented in this study).

Author Contributions: Conceptualization, A.O., A.P. and W.K.; methodology, A.O., A.P., K.K. and W.K.; software, A.M., J.A.D.; validation, A.O., A.P.; formal analysis, A.O., A.M.; investigation, A.O., A.M.; resources, K.K., W.K.; data curation, A.M., J.A.D., J.R. writing-original draft preparation, A.O.; writing—review and editing, A.P., K.K., W.K.; visualization, A.M., J.A.D.; project administration, A.O., A.P.; funding acquisition, A.O., A.P., K.K., W.K. All authors have read and agreed to the published version of the manuscript.

Funding: This work was funded by "Project financially supported by Minister of Education and Science in the range of the program entitled "Regional Initiative of Excellence" for the years 2019-2022, Project No. 010/RID/2018/19, amount of funding 12.000.000 PLN." and as part of a comprehensive study financed by the University of Warmia and Mazury in Olsztyn (Grant No. 30.610.009-110).

Institutional Review Board Statement: Not applicable.

Informed Consent Statement: Not applicable.

Data Availability Statement: Not applicable.

Conflicts of Interest: The authors declare no conflict of interest.

\section{References}

1. Stuper-Szablewska, K.; Perkowski, J. Contamination of wheat grain with microscopic fungi and their metabolites in Poland in 2006-2009. Ann. Agric. Environ. Med. 2014, 21, 504-509. [CrossRef] [PubMed]

2. Vaughan, M.; Backhouse, D.; Ponte, E.M.D. Climate change impacts on the ecology of Fusarium graminearum species complex and susceptibility of wheat to Fusarium head blight: A review. World Mycotoxin J. 2016, 9, 685-700. [CrossRef] 
3. Vujanovic, V.; Mavragani, D.; Hamel, C. Fungal communities associated with durum wheat production system: A characterization by growth stage, plant organ and preceding crop. Crop Prot. 2012, 37, 26-34. [CrossRef]

4. Pastuszak, J.; Szczerba, A.; Dziurka, M.; Hornyák, M.; Kope'c, P.; Szklarczyk, M.; Płazek, A. Physiological and Biochemical Response to Fusarium culmorum Infection in Three Durum Wheat Genotypes at Seedling and Full Anthesis Stage. Int. J. Mol. Sci. 2021, 22, 7433. [CrossRef]

5. Obanor, F.; Chakraborty, S. Aetiology and toxigenicity of Fusarium graminearum and F. pseudograminearum causing crown rot and head blight in Australia under natural and artificial infection. Plant Pathol. 2014, 63, 1218-1229. [CrossRef]

6. Leslie, J.F.; Moretti, A.; Mesterházy, Á.; Ameye, M.; Audenaert, K.; Singh, P.K.; Richard-Forget, F.; Chulze, S.N.; Del Ponte, E.M.; Chala, A.; et al. Key Global Actions for Mycotoxin Management in Wheat and Other Small Grains. Toxins 2021, 13, 725. [CrossRef]

7. Figueroa, M.; Hammond-Kosack, K.E.; Solomon, P.S. A review of wheat diseases-A field perspective. Mol. Plant Pathol. 2018, 19, 1523-1536. [CrossRef]

8. $\quad$ van der Fels-Klerx, H.J.; de Rijk, T.C.; Booij, C.J.H.; Goedhart, P.W.; Boers, E.A.M.; Zhao, C.; Waalwijk, C.; Mol, H.G.J.; van der Lee, T.A.J. Occurrence of Fusarium Head Blight species and Fusarium mycotoxins in winter wheat in The Netherlands in 2009. Food Add. Contam. Part A 2012, 29, 1716-1726. [CrossRef]

9. Somma, S.; Petruzzella, A.L.; Logrieco, A.F.; Meca, G.; Cacciola, O.S.; Moretti, A. Phylogenetic analyses of Fusarium graminearum strains from cereals in Italy, and characterization of their molecular and chemical chemotypes. Crop. Past. Sci. 2014, 65, 52-61. [CrossRef]

10. Lenc, L.; Czecholiński, G.; Wyczling, D.; Turów, T.; Kaźmierczak, A. Fusarium head blight (FHB) and Fusarium spp. on grain of spring wheat cultivars grown in Poland. J. Plant Protect. Res. 2015, 55, 266-277. [CrossRef]

11. Okorski, A.; Polak-Śliwińska, M.; Karpiesiuk, K.; Pszczółkowska, A.; Kozera, W. Real time PCR: A good toll to estimate mycotoxin contamination in pig diets. World Mycotoxin J. 2017, 10, 219-228. [CrossRef]

12. Pszczółkowska, A.; Okorski, A.; Olszewski, J.; Jarmołkowicz, J. Fungal pathogens of the genus Fusarium in winter wheat protected with fungicides in north-eastern Poland. Acta Agrobot. 2013, 66, 95-106. [CrossRef]

13. Sadowski, C.Z.; Lenc, L.; Kuś, J. Fusarium head blight and Fusarium spp. on grain of winter wheat, a mixture of cultivars and spelt grown in organic system. J. Res. Appl. Agric. Eng. 2010, 55, 79-83.

14. Buerstmayr, H.; Adam, G.; Lemmens, M. Resistance to head blight caused by Fusarium spp. in Wheat'. In Disease Resistance in Wheat; Sharma, I., Ed.; MPG Books Group: Bodmin, UK, 2012; pp. 236-276.

15. Geißinger, C.; Gastl, M.; Becker, T. Enzymes from Cereal and Fusarium Metabolism Involved in the Malting Process-A Review. J. Am. Soc. Brew. Chem. 2021, 80,1-16. [CrossRef]

16. National Oceanic \& Atmospheric Administration-Earth System Research Laboratory. Trends in Atmospheric Carbon Dioxide. 2020. Available online: https:/ / www.esrl.noaa.gov/gmd/ccgg/trends (accessed on 27 January 2022).

17. Palit, P.; Kudapa, H.; Zougmore, R.; Kholova, J.; Whitbread, A.; Sharma, M.; Varshney, R.K. An integrated research framework combininggenomics, systems biology, physiology, modelling and breeding forlegume improvement in response to elevated CO2 under climatechange scenario. Curr. Plant Biol. 2020, 22, 10014. [CrossRef]

18. Lamichaney, A.; Maity, A. Implications of rising atmospheric carbon dioxide concentration on seed quality. Int. J. Biometeorol. 2021, 65, 805-812. [CrossRef]

19. Heinze, W.; Schreiber, D. Eine neue Kartierung der Winterhärtezonen für Gehölze in Europa (Anew mapping of winter hardiness zones for woody vegetation in Europe). Mitt. Deutsch. Dendrol. Gesellschaft. 1984, 75, 11-56.

20. Dawson, I.K.; Russell, J.; Powell, W.; Steffenson, B.; Thomas, W.T.B.; Waugh, R. Barley: A Translational Model for Adaptation to Climate Change. New Phytol. 2015, 206, 913-931. [CrossRef]

21. Linkmeyer, A.; Hofer, K.; Rychlik, M.; Herz, M.; Hausladen, H.; Huckelhoven, R.; Hess, M. Influence of Inoculum and Climatic Factors on the Severity of Fusarium Head Blight in German Spring and Winter Barley. Food Addit. Contam. Part A Chem. Anal. Control Expo Risk Assess. 2016, 33, 489-499. [CrossRef]

22. Snowarski, M. Strefy mrozoodporności-Nowe mapy. Szkótkarstwo 2012, 6, 60-67.

23. Wegulo, S. Factors influencing deoxynivalenol accumulation in small grain cereals. Toxins 2012, 4, 1157-1180. [CrossRef] [PubMed]

24. Tola, M.; Kebede, B.; Yildiz, F. Occurrence, importance and control of mycotoxins: A review. Cogent Food Agric. $2016,2,1191103$. [CrossRef]

25. McMullen, M.; Bergstrom, G.; De Wolf, E.; Dill-Macky, R.; Hershman, D.; Shaner, G.; Van Sanford, D. A Unified Effort to Fight an Enemy of Wheat and Barley: Fusarium Head Blight. Plant Dis. 2012, 96, 1712-1728. [CrossRef] [PubMed]

26. Moretti, A.; Pascale, M.; Logrieco, A.F. Mycotoxin risks under a climate change scenario in Europe. Tr. Food Sci. Technol. 2019, 84, 38-40. [CrossRef]

27. Edwards, S.G. Fusarium mycotoxin content of UK organic and conventional wheat. Food Addit. Contam. 2009, 26, 496-506. [CrossRef]

28. Mielniczuk, E.; Skwaryło-Bednarz, B. Fusarium Head Blight, Mycotoxins and Strategies for Their Reduction. Agronomy 2020, 10, 509. [CrossRef]

29. Vogelgsang, S.; Beyer, M.; Pasquali, M.; Jenny, E.; Musa, T.; Bucheli, T.D.; Wettstein, F.E.; Forrer, H.-R. An eight-year survey of wheat shows distinctive effects of cropping factors on different Fusarium species and associated mycotoxins. Eur. J. Agron. 2019, 105, 62-77. [CrossRef] 
30. Piacentini, K.C.; Rocha, L.O.; Savi, G.D.; Carnielli-Queiroz, L.; De Carvalho Fontes, L.; Correa, B. Assessment of Toxigenic Fusarium Species and Their Mycotoxins in Brewing Barley Grains. Toxins 2019, 11, 31. [CrossRef]

31. Timmusk, S.; Nevo, E.; Ayele, F.; Noe, S.; Niinemets, Y. Fighting Fusarium Pathogens in the Era of Climate Change: A Conceptual Approach. Pathogens 2020, 9, 419. [CrossRef]

32. Nathanail, A.; Varga, E.; Meng-Reiterer, J.; Bueschl, C.; Michlmayr, H. Metabolism of Fusarium Mycotoxins T2 toxin, HT-2, and in wheat. J. Agric. Food Chem. 2015, 63, 7862-7872. [CrossRef]

33. Smith, M.C.; Madec, S.; Coton, E. Natural Co-Occurrence of Mycotoxins in Foods and Feeds and Their in vitro Combined Toxicological Effects. Toxins 2016, 8, 94. [CrossRef] [PubMed]

34. Teller, R.S.; Schmidt, R.J.; Whitlow, L.W. Effect of physical damage to ears of corn before harvest and treatment with various additives on the concentration of mycotoxins, silage fermentation, and aerobic stability of corn silage. J. Dairy Sci. 2012, 95, 1428-1436. [CrossRef] [PubMed]

35. Spanic, V.; Horvat, D.; Drezner, G.; Zdunic, Z. Changes in protein composition in the grain and malt after Fusarium infection dependently of wheat resistance. Pathogens 2019, 8, 112. [CrossRef] [PubMed]

36. Beccari, G.; Arellano, C.; Covarelli, L.; Tini, F.; Sulyok, M.; Cowger, C. Effect of wheat infection timing on Fusarium head blight causal agents and secondary metabolites in grain. Int. J. Food Microbiol. 2019, 90, 214-225. [CrossRef] [PubMed]

37. Covarelli, L.; Beccari, G.; Prodi, A.; Generotti, S.; Etruschi, F.; Juan, C.; Ferrer, E.; Mañes, J. Fusarium species, chemotype characterisation and trichothecene contamination of durum and soft wheat in an area of central Italy. J. Sci. Food Agric. 2015, 95, 541-551. [CrossRef] [PubMed]

38. Häller, G.B.; Munich, M.; Kleijer, G.; Mascher, F. Characterisation of kernel resistance against Fusarium infection in spring wheat by baking quality and mycotoxin assessments. Eur. J. Plant Pathol. 2008, 120, 61-68.

39. Marzec-Schmidt, K.; Börjesson, T.; Suproniene, S.; Jędryczka, M.; Janavičienè, S.; Góral, T.; Karlsson, I.; Kochiieru, Y.; Ochodzki, P.; Mankevičienè, A.; et al. Modelling the Effects of Weather Conditions on Cereal Grain Contamination with Deoxynivalenol in the Baltic Sea Region. Toxins 2021, 13, 737. [CrossRef]

40. Bryła, M.; Ksieniewicz-Woźniak, E.; Yoshinari, T.; Waśkiewicz, A.; Szymczyk, K. Contamination of Wheat Cultivated in Various Regions of Poland during 2017 and 2018 Agricultural Seasons with Selected Trichothecenes and Their Modified Forms. Toxins 2019, 11, 88. [CrossRef]

41. Klem, K.; Vanova, M.; Hajslova, J.; Lancova, K.; Sehnalova, M. A neural network model for prediction of deoxynivalenol content in wheat grain based on weather data and preceding crop. Plant Soil Env. 2007, 53, 421-429. [CrossRef]

42. Bensassi, F.; Mahdi, C.; Bacha, H.; Hajlaoui, M.R. Survey of the mycobiota of freshly harvested wheat grains in the main production areas of Tunisia. Afr. J. Food Sci. 2011, 5, 292-298.

43. Desjardins, A.E. Fusarium mycotoxins. In Chemistry, Genetics, and Biology; APS Press: St. Paul, MN, USA, 2006.

44. González-Osnaya, L.; Farrés, A. Deoxynivalenol and zearalenone in Fusarium-contaminated wheat in Mexico City. Food Addit. Contam. Part B. 2011, 4, 71-78. [CrossRef]

45. Yoshizawa, T. Thirty-five Years of Research on Deoxynivalenol, a Trichothecene Mycotoxin: With Special Reference to Its Discovery and Co-occurrence with Nivalenol in Japan. Food Saf. 2013, 1, 2013002. [CrossRef]

46. Winter, M.; Koopmann, B.; Döll, K.; Karlovsky, P.; Kropf, U.; Schlüter, K.; Tiedemann, A. Mechanisms regulating grain contamination with trichothecenes trans-located from the stem base of wheat (Triticum aestivum) infected with Fusarium culmorum. Phytopathology 2013, 103, 682-689. [CrossRef] [PubMed]

47. Berthiller, F.; Crews, C.; Dall'Asta, C.; Saeger, S.D.; Haesaert, G.; Karlovsky, P.; Stroka, J. Masked mycotoxins: A review. Mol. Nutr. Food Res. 2012, 57, 165-186. [CrossRef] [PubMed]

48. Xu, X.M.; Nicholson, P.; Thomsett, M.A.; Simpson, D.; Cooke, B.M.; Doohan, F.M.; Brennan, J.; Monaghan, S.; Moretti, A.; Mule, G.; et al. Relationship between the fungal complex causing Fusarium head blight of wheat and environmental conditions. Phytopathology 2008, 98, 69-78. [CrossRef] [PubMed]

49. Siou, D.; Gélisse, S.; Laval, V.; Suffert, F.; Lannou, C. Mutual Exclusion between Fungal Species of the Fusarium Head Blight Complex in a Wheat Spike. Appl. Environ. Microbiol. 2015, 81, 4682-4689. [CrossRef] [PubMed]

50. Logrieco, A.; Mulè, G.; Moretti, A.; Bottalico, A. Toxigenic Fusarium species and mycotoxins associated with maize ear rot in Europe. Eur. J. Plant Pathol. 2002, 108, 597-609. [CrossRef]

51. Ederli, L.; Beccari, G.; Tini, F.; Bergamini, I.; Bellezza, I.; Romani, R.; Covarelli, L. Enniatin B and Deoxynivalenol Activity on Bread Wheat and on Fusarium Species Development. Toxins 2021, 13, 728. [CrossRef] [PubMed]

52. Eranthodi, A.; Schneiderman, D.; Harris, L.J.; Witte, T.E.; Sproule, A.; Hermans, A.; Overy, D.P.; Chatterton, S.; Liu, J.; Li, T.; et al. Enniatin production influences Fusarium avenaceum virulence on potato tubers, but not on durum wheat or peas. Pathogens 2020, 9, 75. [CrossRef]

53. Pollard, A.T.; Okubara, P.A. Real-time PCR quantification of Fusarium avenaceum in soil and seeds. J. Microbiol. Methods 2019, 157, 21-30. [CrossRef]

54. Vogelgsang, S.; Musa, T.; Bänziger, I.; Kägi, A.; Bucheli, T.D.; Wettstein, F.E.; Pasquali, M.; Forrer, H.R. Fusarium Mycotoxins in Swiss Wheat: A Survey of Growers' Samples between 2007 and 2014 Shows Strong Year and Minor Geographic Effects. Toxins 2017, 9, 246. [CrossRef] [PubMed]

55. Leslie, J.F.; Summerell, B.A. The Fusarium Laboratory Manual; Blackwell Publishing: Hoboken, NY, USA, 2006; pp. 81-159. 
56. Uhlig, S.; Jestoi, M.; Parikka, P. Fusarium avenaceum- the north European situation. Int. J. Food Microbiol. 2007, 119, 17-24. [CrossRef] [PubMed]

57. Byamukama, E.; Shaukat, A.; Kleinjan, J.; Yabwalo, D.N.; Graham, C.; Caffe-Treml, M.; Mueller, N.D.; Rickertsen, R.; Berzonsky, W.A. Winter Wheat Grain Yield Response to Fungicide Application is Influenced by Cultivar and Rainfall. Plant Pathol. J. 2019, 35, 63-70. [CrossRef] [PubMed]

58. Doohan, F.M.; Brennan, J.; Cooke, B.M. Influence of climatic factors on Fusarium species pathogenic to cereals. Eur. J. Plant Pathol. 2003, 109, 755-768. [CrossRef]

59. Reis, E.M.; Boareto, C.; Durante Danelli, A.L.; Zoldan, S.M. Anthesis, the infectious process and disease progress curves for Fusarium head blight in wheat. Summa Phytopathol. 2016, 42, 134-139. [CrossRef]

60. Postic, J.; Cosic, J.; Vrandecic, K.; Jurkovic, D.; Saleh, A.A.; Leslie, J.F. Diversity of Fusarium Species Isolated from Weeds and Plant Debris in Croatia. J. Phytopathol. 2011, 160, 76-81. [CrossRef]

61. Shah, L.; Ali, A.; Yahya, M.; Zhu, Y.; Wang, S.; Si, H.; Ma, C. Integrated control of Fusarium head blight and deoxynivalenol mycotoxin in wheat. Plant Pathol. 2017, 67, 532-548. [CrossRef]

62. Mesterházy, Á.; Tóth, B.; Szabó-Hevér, Á.; Varga, J.; Lehoczki-Krsjak, S. Node Infection Caused by Fusarium graminearum in Wheat. Cereal Res. Commun. 2008, 36, 471-475. [CrossRef]

63. Manstretta, V.; Gourdain, E.; Rossi, V. Deposition patterns of Fusarium graminearum ascospores and conidia within a wheat canopy Europ. J. Plant Pathol. 2015, 143, 873-880. [CrossRef]

64. Scala, V.; Aureli, G.; Cesarano, G.; Incerti, G.; Fanelli, C.; Scala, F.; Reverberi, M.; Bonanomi, G. Climate, Soil Management, and Cultivar Affect Fusarium Head Blight Incidence and Deoxynivalenol Accumulation in Durum Wheat of Southern Italy. Front. Microbiol. 2014, 7, 1014. [CrossRef]

65. Bankina, B.; Bimšteine, G.; Neusa-Luca, I.; Roga, A.; Fridmanis, D. What influences the composition of fungi in wheat grains. Acta Agrobot. 2017, 70, 1726. [CrossRef]

66. Kulik, T.; Jestoi, M. Quantification of Fusarium poae DNA and associated mycotoxins in asymptomatically contaminated wheat Int. J. Food Microbiol. 2009, 130, 233-237. [CrossRef] [PubMed]

67. Xu, X.-M.; Monger, W.; Ritieni, A.; Nicholson, P. Effect of temperature and duration of wetness during initial infection periods on disease development, fungal biomass and mycotoxin concentrations on wheat inoculated with single, or combinations of Fusarium species. Plant Pathol. 2007, 56, 943-956. [CrossRef]

68. Wang, Y.; Hou, Y.; Mao, X.; Liu, F.; Zhou, M. Temperature-Responded Biological Fitness of Carbendazim-Resistance Fusarium graminearum Mutants Conferring the F167Y, E198K, and E198L Substitutions. Plant Dis. 2021, 105, 3522-3530. [CrossRef] [PubMed]

69. Wenda-Piesik, A.; Lemańczyk, G.; Twarużek, M.; Błajet-Kosicka, A.; Kazek, M.; Grajewski, J. Fusarium head blight incidence and detection of Fusarium toxins in wheat in relation to agronomic factors. Eur. J. Plant Pathol. 2017, 149, 515-531. [CrossRef]

70. Drakopoulos, D.; Kägi, A.; Gimeno, A.; Six, J.; Jenny, E.; Forrer, H.-R.; Vogelgsang, S. Prevention of Fusarium head blight infection and mycotoxins in wheat with cut-and-carry biofumigation and botanicals. Field Crops Res. 2020, 246, 107681. [CrossRef]

71. Rowlandson, T.; Gleason, M.; Sentelhas, P.; Gillespie, T.; Thomas, C.; Hornbuckle, B. Reconsidering leaf wetness duration determination for plant disease management. Plant Dis. 2015, 99, 310-319. [CrossRef]

72. Hofer, K.; Huckelhoven, R.; Hess, M. Analysis of Archive Samples of Spring and Winter Barley Support an Increase in Individual Fusarium Species in Bavarian Barley Grain over the Last Decades. J. Plant Dis. Prot. 2019, 126, 247-254. [CrossRef]

73. Pigati, R.L.; Dernoeden, P.H.; Grybauskas, A.P.; Momen, B. Simulated rainfall and mowing impact fungicide performance when targeting dollar spot in creeping bentgrass. Plant Dis. 2010, 94, 596-603. [CrossRef]

74. Bryła, M.; Ksieniewicz-Woźniak, E.; Waśkiewicz, A.; Szymczyk, K.; Jędrzejczak, R. Natural Occurrence of Nivalenol, Deoxynivalenol, and Deoxynivalenol-3-Glucoside in Polish Winter Wheat. Toxins 2018, 10, 81. [CrossRef]

75. ISO-24333; Cereal and Cereal Products-Sampling. ISO: Geneva, Switzerland, 2009.

76. Gerlach, W.; Nirenberg, H. The Genus Fusarium-A Pictorial Atlas; Biologische Bundesanstalt für Land- und Forstwirtschaft: Berlin, Germany, 1982.

77. Watanabe, I.; Kakishima, M.; Adachi, Y.; Nakajima, H. Potential mycotoxin productivity of Alternaria alternata isolated from garden trees. Mycotoxins 2007, 57, 34-45. [CrossRef]

78. Livak, K.J.; Schmittgen, T.D. Analysis of Relative Gene Expression Data Using Real-Time Quantitative PCR and the $2-\Delta \Delta C T$ Method. Methods 2001, 25, 402-408. [CrossRef] [PubMed]

79. Pfaffl, M.W. A new mathematical model for relative quantification in real-time RT-PCR. Nucleic Acids Res. 2001, 29, e45. [CrossRef] [PubMed]

80. Kulik, T.; Jestoi, M.; Okorski, A. Development of TaqMan assays for the quantitative detection of Fusarium avenaceum/Fusarium tricinctum and Fusarium poae esyn1 genotypes from cereal grain. FEMS Microbiol. Lett. 2011, 314, 49-56. [CrossRef] [PubMed]

81. Nicolaisen, M.; Supronienè, S.; Nielsen, L.K.; Lazzaro, I.; Spliid, N.H.; Justesen, A.F. Real-time PCR for quantification of eleven individual Fusarium species in cereals. J. Microbiol. Methods 2009, 76, 234-240. [CrossRef]

82. Vegi, A.; Wolf-Hall, C.E. Multiplex real-time PCR method for detection and quantification of mycotoxigenic fungi belonging to three different genera. J. Food Sci. 2013, 78, M70-M76. [CrossRef] 